Vol. 13, n² | 2009

Varia

\title{
Eyerman (Ron), The Assassination of Theo Van Gogh. From Social Drama to Cultural Trauma
}

Durham, Duke University Press, 2008, 220 pp., ISBN 9780822344063

Pieter Spierenburg

\section{(2) OpenEdition}

\section{Journals}

Electronic version

URL: https://journals.openedition.org/chs/1126

DOI: $10.4000 /$ chs. 1126

ISSN: 1663-4837

Publisher

Librairie Droz

Printed version

Date of publication: 1 October 2009

Number of pages: 150-153

ISBN: 978-2-600-01387-1

ISSN: 1422-0857

\section{Electronic reference}

Pieter Spierenburg, "Eyerman (Ron), The Assassination of Theo Van Gogh. From Social Drama to Cultural

Trauma", Crime, Histoire \& Sociétés / Crime, History \& Societies [Online], Vol. 13, n² | 2009, Online since 01 October 2009, connection on 22 March 2022. URL: http://journals.openedition.org/chs/1126 ; DOI: https://doi.org/10.4000/chs. 1126 
of violence infringed the rule of law but their toleration by the police only distorted the legitimacy of the state with the Jews: it didn't undermine the state and its legitimacy with the population (p. 17). I don't consider legality a sensible concept to compare and understand European policing, because legal traditions differ widely in Europe and formal rules and regulations only play a minor role in determining police practice. In addition, I regret that, apart from Dunnage, the editor and most authors fail to appreciate the importance of police interaction with civil society, even or maybe especially in authoritarian and totalitarian political systems. One misses badly themes like denunciations by citizens and the impact of moral panic on police personnel.

The collection of essays is rounded off by Emsley with an attempt to recognize some similarities and differences in policing in Europe during the $20^{\text {th }}$ century. This kind of effort is rare. Earlier comparisons restricted themselves to national police systems. Emsley can only lean on patchy knowledge, so one can but expect limited results. He correctly resists the temptation to think that policing in dictatorships totally differs from policing in democracies and points out important similarities in institutional reactions on war and the threat of war, in public relations and in moral dilemmas of individual policemen confronted with dictatorship. These similarities may in the distant future offer starting points for a comprehensive study of policing in Europe.

\author{
Guus Meershoek \\ Twente University \\ Cubicus Building - PO Box 217 \\ NL-7500AE Enschende
}

\title{
Eyerman (Ron), The Assassination of Theo Van Gogh. From Social Drama to Cultural Trauma, Durham, Duke University Press, 2008, 220 pp., ISBN 9780822344063.
}

Ron Eyerman is a Yale sociologist, presumably with Dutch roots. His previous publications deal with a wide range of subjects; this book is about a recent event with repercussions throughout the world. Let me recall, for readers not living in the Netherlands: Theo van Gogh, a well-known film maker, tv host and publicist, was murdered on November 2, 2004, while riding his bike in the early morning. Muslim radicals hated him for directing the short film Submission, meant to denounce the treatment of women under Islam. The initiative for that movie had come from Ayaan Hirsi Ali, a Somali refugee and member of the Dutch parliament. Whereas her security was upheld in a full-scale protection program, Van Gogh, with characteristic bravado, had always refused protection. The killer, Mohammed Bouyeri, was a second-generation Moroccan immigrant who had been in contact with other Islamic radicals. With a knife he pinned a note, directed at Hirsi Ali in particular, on the victim's dead body. The murderer had hoped to be shot by the police and become a martyr, but he was arrested and sentenced to life imprisonment. The issue of terrorism and the fact that the victim was the great-grandson and namesake of Vincent van Gogh's brother ensured international publicity for the case.

A murder like this calls for a meticulous examination of its political and sociocultural context, which Eyerman provides, along with an analysis of the trauma that the event supposedly caused among the population. The book contains a number of 
interesting observations. The author presents details about the killer's biography, for example, that at least this reviewer had not read in the regular press. He makes a thoughtful comparison between Bouyeri and Hirsi Ali as two opposed models of integration. The first had six years of higher education, was active in affairs of his community, then felt he could get no further and embraced a radical faith that put him in opposition to the established majority. The second dropped her faith, was a student likewise and became a successful politician and spokesperson for women's rights. The author amply discusses whether Hirsi Ali was the killer's «real target» or Van Gogh along with her. He speculates that Bouyeri had obtained official authorization from a clergyman to «execute» Van Gogh, even though the latter had never been a Muslim. This would include Europe into the geographic area where extremists feel legitimated in killing prominent opponents. A detail that was also unknown to me concerns the video that serves to acquaint newly arrived immigrants with Dutch society. It appears to be available in a full version and a censored one with images of nude breasts and men kissing left out.

On the other hand, the book contains several mistakes. Some are minor, such as in the case of the 1960s writer Jan Cremer whose name is given first (p. 30) as Cramer. The word «media» is sometimes treated as if it were singular. The author has queen Beatrix install chaos (p. 45). There are odd translations such as «the integration of minorities must be openly discussed» for «de integratie van minderheden moet met lef worden aangepakt» (p. 107, referring to a newspaper headline), where something like «faced with courage» would have been closer. The account of the video just mentioned (p. 121) confuses the Union of Utrecht with the Peace of Münster and then the French Revolution with the revolutions of 1848 (the video's or Eyerman's mistakes?). These are only some of the errors, misspellings and oddities. Then there are elements that the author, as a relative outsider to Dutch society, misses. At the beginning he alternates between the killer's full name and that of Mohammed B., deciding on p. 7 to use mostly the latter form because this is the Dutch habit. Eyerman does not mention that it has long been a voluntary custom in the Dutch media to name suspects and convicts only by initials and that this is considered part of their human rights to privacy. This custom has come under pressure in the present climate of toughness. Indeed, I first read the full name of Bouyeri on a plane in a popular magazine where a columnist stated that, since the murderer had committed such a heinous crime, he did not deserve the privacy of initials. Another omission occurs when Eyerman mentions a plan for a neighborhood youth center that Bouyeri championed but the subsidy for which was denied in 2002. Angrily, Bouyeri exclaimed to the civil servant: «Are we so clever or are you so stupid?» (p. 59) Eyerman fails to note that this is a paraphrase of a famous dictum by Louis van Gaal, former coach of Ajax and the national team. (His source, Albert Benschop, tells me, as expected, that he found this too obvious to mention.) And this quote appears only one page after Eyerman has discussed Bouyeri's attitudes to the Dutch and foreign soccer teams during the European championship of 2000. Finally, it is intriguing that Eyerman fails to mention Van Gogh's words, in writing and meant comically, «what a smell of caramel here; today they burn only the diabetic Jews.» This phrase was cited over and again in the press to underline that, although a murder in order to curb the free word was utterly wrong, Van Gogh was not OK either. In fact, Eyerman quickly passes over Van Gogh's anti-Semitism, because in the book's social drama story the Dutch Muslims, in need of protection as a group, have replaced the Jews of the German occupation. 
Other critical remarks have to do with the question what the author's aims are. Is it to provide non-Dutch readers with the tale of the murder and an understanding of the society that gave rise to it? Or is his main purpose to refine the sociological theories of social drama and cultural trauma that figure in the subtitle? The first possible purpose, a readable story for non-Dutch people interested in the case, is not very well served. The book's structure is simply too chaotic for that. It is repetitive, stressing for example several times the significance of Van Gogh being killed in a busy street during rush hour. The book jumps from one aspect of Dutch society to another, then to a third and back again. Even the chapter devoted to the biographies of the three main protagonists contains digressions about tourism in Amsterdam, the Rushdie affair or globalization. Furthermore, Eyerman seems unable to decide whether the book is about the murder of Van Gogh only or equally about that of the politician Pim Fortuyn two and a half years previously. Incidentally, he repeats phony experts' statement, made at the occasion, that Fortuyn's was the first political murder in the Netherlands after more than 300 years. The book's chaotic structure is reflected in the numerous cross-references. Generally, I am in favor of them, but here we read too often phrases like «this will be discussed further on», to be replaced gradually by «as discussed previously».

Perhaps the book's structure is based on the composition of the author's theoretical framework, but it eludes me exactly how. At the beginning of the last chapter the author claims to have done three things in the preceding five chapters: present the facts with the help of performance theory, discuss representation making use of discourse theory, and understand the emotions in terms of collective memory. The contribution of the theory of cultural trauma is to begin only after this. Eyerman promises that this theory will reveal «sores in Dutch society... that were very deeply hidden» (p. 162) and culture structures that are «deeply buried» (p. 164). At the book's end these promises are unfulfilled and we remain ignorant about the nature of all this deepness. As an alternative, I would have preferred Norbert Elias' model of established vs. outsiders as a theoretical instrument for understanding the position and ideas of the various groups in Dutch society.

At a more concrete level, Eyerman wants to place the murder against the background of Dutch history. But what exactly is the crucial episode here? Very early on he maintains that it is the Second World War. Indeed, all historians agree that WW II has finally replaced the sixteenth-century revolt against Spain as the principal point of reference for the Dutch we-image. Yet, several times Eyerman returns to that revolt, proclaiming the distinctly Calvinist character of the Dutch native population. Next, the loss of colonies after the war is important. Eyerman also gives much room, and rightly so, to the cultural transformations of the rebellious $1960 \mathrm{~s}$. He even calls Van Gogh «the product» of the sixties (p. 134), which is stretching the evidence for someone born in 1957. In my view, the sixties are more relevant as a historical background to the relationships between the native majority and Muslim communities than WW II. Natives feel that Muslims are threatening the accomplishments of the 1960s, like nudity in visual arts, women's rights and freedom from religious bigotry. They view the Netherlands as a secularized society, not part of a Christian civilization à la Samuel Huntington. Eyerman partly acknowledges this, but he wavers between this interpretation and Huntington. Within the Dutch multicultural society he pays attention almost exclusively to Moroccans and Turks. The Surinamese (of whom only 15\% are Muslims) and the Antillians (although the youth is considered a problem group) present much less of a challenge to 1960s values. Many of them, on the other hand, press for a more prominent place of sla- 
very in collective memory and some find its commemoration more important than that of the Second World War and the Holocaust. This is intriguing in the light of Eyerman's observation that the Dutch, or any European nation, do not feel collective guilt about the (colonial) past, like many white Americans feel ashamed about slavery.

One historical viewpoint is completely absent. I do not question the publisher's wisdom in sending this book for review to CHS, but there is not a single reference to any publication in the field of crime history. It might have been interesting to situate the assassination of Theo van Gogh within the history of political murder or to compare the case with microhistories that have been written about notorious murders in earlier periods. To conclude, this book is useful in some respects, but it also has definite shortcomings.

Pieter Spierenburg spierenburg@fhk.eur.nl

\section{Fyson (Donald), Magistrates, Police, and People. Everyday Criminal Justice in Quebec and Lower Canada (1764-1837), Toronto, University of Toronto Press, 2007, 467 pp., ISBN 080209223 3. Tables, illus., bibliog., index.}

The sub-title of this book describes effectively its contents: a study exclusively of the lower courts of magistrates from the establishment of common law courts in the 1760s down to the revolutionary reform years of the 1840s. Fyson draws his evidence primarily from the manuscript court records themselves. These include the records of the Clerk of the Peace and of the Crown for the Montreal Quarter and Weekly Sessions of the Peace from 1785; the Quebec Quarter, Weekly and Special Sessions from 1802; the partial and scattered records of the Courts of King's Bench; the calendars and registers of the Montreal and Quebec Houses of Correction primarily from 1810; the administrative records of the City of Montreal from the 1790s and City Council papers from 1833; and the legislative and colonial records. Combined with more than 60 pages of notes and a detailed bibliography of primary sources and secondary works of 28 pages, this is perhaps the most solid research study of the criminal courts and the criminal law in Quebec since the pioneering work of Jean-Marie Fecteau ${ }^{10}$.

The author is a prolific scholar early in his career who has published ten articles/book chapters in his first decade, and has co-authored the major sourcebook on the courts of Quebec in this era and beyond ${ }^{11}$. Fyson has, essentially, rewritten the history of crime, policing, and criminal justice in Quebec at a level that has not been matched for any colony or province in Canada. Drawing from the work of socio-legal historians of Britain, France and the United States, he leaves few stones untouched in his magisterial study. While controversial in places, this is a book that

10 Jean-Marie Fecteau, Un nouvel ordre des choses la pauvreté, le crime, l'État au Québec, de la fin du XVIII ' siècle à 1840, Montréal, VLB, 1989; and La liberté du pauvre sur la régulation du crime et de pauvreté au XIX' siècle québécois, Montréal, VLB, 2004.

11 Donald Fyson, Evelyn Kolish, Virginia, Schweitzer, The Court Structure of Quebec and Lower Canada, 1764 to 1860 , Montreal, Montreal history group, $1^{\text {st }}$ ed. 1994; and $2^{\text {nd }}$ rev. ed. 1997), at [www.hst.ulaval.ca/profs/dfyson/courtstr/]. 